\title{
Antibiotic Associated Diarrhea and Incidence of Clostridium difficile Infection and Colonization in Infants and Children in Tanta University Hospital, Egypt
}

\author{
Marwa Ahmed Ali Abd El-Wahab ${ }^{1 *}$, Ahmed Mohamed Naeem ${ }^{2}$, Abd EL-Rahman \\ Mohamed EL-Mashad ${ }^{2}$ and Nehad Refhat Mostafa Sallam² \\ ${ }^{1}$ Department of Microbiology and Immunology, Faculty of Medicine, Tanta, Egypt \\ ${ }^{2}$ Department of Pediatrics, Faculty of Medicine, Tanta, Egypt
}

*Corresponding author

\begin{tabular}{|c|c|}
\hline & A B S T R A C T \\
\hline Keywords & Injudicious use of antibiotics in hospitalized patients increases the risk of \\
\hline $\begin{array}{l}\text { CDAD, } \\
\text { C. difficile } \\
\text { toxins, } \\
\text { C. difficile } \\
\text { colonization, } \\
\text { Stool culture, } \\
\text { Egypt }\end{array}$ & $\begin{array}{l}\text { Clostridium difficile associated diarrhea (CDAD). This study was conducted to } \\
\text { determine the incidence of } C \text {. difficile as a cause of antibiotic associated diarrhea in } \\
\text { pediatric patients in our hospital. Sixty infants and children with a history of } \\
\text { antibiotic intake whether having diarrhea or not and } 30 \text { age and sex matched } \\
\text { patients with no history of antibiotic intake were studied prospectively over a } \\
\text { period of one year. Stool samples were processed for } C \text {. difficile isolation and } \\
\text { examined for } C \text {. difficile toxin A and B by the enzyme-linked immunosorbent } \\
\text { assay. } 26 \text { out of } 60 \text { cases }(43.3 \%) \text { suffered from diarrhea. Only }(22 / 60) \text { showed }\end{array}$ \\
\hline & \\
\hline $\begin{array}{l}\text { Accepted: } \\
25 \text { December } 2015 \\
\text { Available Online: } \\
\text { 10 January } 2016\end{array}$ & $\begin{array}{l}\text { remaining } 4 \text { patients had no diarrhea and only colonized with toxigenic } C \text {. difficile } \\
\text { representing } 11.8 \% \text { of total } 34 \text { cases without diarrhea. Toxin A and B were } \\
\text { detected in } 16 \text { patients including } 4 \text { asymptomatic carriers and } 12 \text { out of } 26 \text { cases } \\
\text { with diarrhea representing } 46.2 \% \text {. The incidence of CDAD in our hospital was } \\
46.2 \% \text {. The asymptomatic carriage rate was } 11.8 \% \text {. }\end{array}$ \\
\hline
\end{tabular}

\section{Introduction}

Extensive and widespread use of broad spectrum antibiotics has increased dramatically in the last decade especially in hospitalized patients. Despite their benefits in treating a lot of human infections, they are incriminated in changing the function and the composition of the intestinal microbiota causing what is called antibiotic associated diarrhea which ranges from mild, benign and self limiting diarrhea up to severe life threatening colitis (Kaneria and Paul, 2012; Hurley and Nguyen, 2002; Kyne et al., 2002; Ferri, 2010).

The disruption happened in the intestinal flora may result in subsequent Clostridium difficile $(C$. difficile) colonization and infection especially in hospitalized patients (Hung et al., 2014; Wilcox, 2003). C. difficile is responsible for about $20 \%$ of all 
cases of antibiotic associated diarrhea and the antibiotic use is considered as the most important risk factor for $C$. difficile associated diarrhoea (CDAD)(Voth and Ballard, 2005; Kaneria and Paul, 2012).

Clostridium difficile toxins $\mathrm{A}$ and $\mathrm{B}$ are mainly the cause of CDAD in infected patients (Knecht et al., 2014). C. difficile infection is classified by $\mathrm{CDC}$ as major public health problem that requires urgent attention (CDC, 2013).

C. difficile was first described in 1935 when it was isolated from stool of healthy individuals so it was classified as commensal (Hall and O'Toole, 1935), it was not known to be a cause of diarrhea until 1978 (Larson et al., 1987).

Infections by $C$. difficile are about to be doubled in the last decade. (Zilberberg et al., $2008_{a, b}$; Sharland et al., 2011). Although the rate and severity of $C$. difficile infections (CDIs) have increased, it is not well estimated as a reason for diarrhea in pediatric patients less than 18 years old (Pokorn et al., 2008; Kim et al., 2012). The main cause for such underestimation is that the asymptomatic carriage rate in pediatrics is considered high about (21-48\%) in neonatal period and early infancy (Hung et al., 2015) and up to $8.3 \%$ of children older than two years of age (Cerquetti et al., 1995).

Although some patients are only carriers for C. difficile with no symptoms they are prone to develop CDI and diarrhea and are considered as a source for CDI as they are associated with skin and environmental contamination and representing a burden for the health care system, thus attention should be paid to such carriers due to their serious clinical importance (Hung et al., 2015).
However CDAD is still not well estimated in Egypt especially in pediatric patients because the anaerobic cultivation of stool samples is not a routine in our country and is somewhat considered expensive. Therefore we undertook a prospective study to assess the incidence of CDAD and asymptomatic carriers in hospitalized non-newborn infants and children received antibiotics for more than 10 days duration admitted to our hospital.

\section{Materials and Methods}

This study was conducted prospectively over one year from August 2014 to September 2015 on 60 non-newborn infants and children with mean age $(49.6 \pm 31)$ months, $50 \%$ males and $50 \%$ females on antibiotics including (Penicillins, aminoglycosides, cephalosporins, carbapenems, clindamycin, quinolones) whether had diarrhea or not and 30 age and sex matched controls with no antibiotic intake admitted to Department of Pediatrics at Tanta University hospital in Egypt. Patients with other infective causes of diarrhea (amoebiasis, acute gastroenteritis, enteric fever, hepatitis A), inflammatory bowel disease, irritable bowel syndrome and other causes of chronic diarrhea were excluded.

A detailed case history including age, sex, type of feeing and duration of antibiotic therapy were collected from patients' medical records. Written consent was taken from parents of each patient

Stool samples were collected in sterile wide mouthed sealed containers from all the studied cases and control and transferred immediately to Microbiology laboratory at faculty of Medicine, Tanta University, Egypt and the samples were processed immediately. All stool samples cultured 
anaerobically on cefoxitin-cycloserine fructose agar (CCFA) (Biomerieux, France). Colonies grown on CCFA plate were presumptively identified as $C$. difficile were subjected to biochemical reactions. The remaining part of all stool samples were then stored at $-80^{\circ} \mathrm{C}$ for further detection of C. difficile A and $\mathrm{B}$ toxins using ELISA kit (Supplied by Diagnostic Automation, Cortez Diagnostics, Inc., USA)

\section{Processing of the Samples}

Stool samples were mixed in a ratio $1: 1$ with PBS to be homogenized and then heat shocked $\left(80^{\circ} \mathrm{C}\right.$ for $10 \mathrm{~min}$.). Samples then centrifuged (at 4000x g for $1 \mathrm{~min}$.)

\section{Isolation and Identification of $C$. difficile}

Culture: 1-2 drops from the supernatant were streaked onto CCFA to obtain single colonies. The plates were then incubated in anaerobic gas pack jar at $37^{\circ} \mathrm{C}$ for $48-72 \mathrm{~h}$ using anaerobic air pack (Oxoid, UK).

On CCFA, circular, yellow, fimbriate colonies of $4 \mathrm{~mm}$ size or larger, Gram positive bacilli with subterminal oval spores having horse stable odour was presumptively identified as $C$. difficile.

Colonies morphologically resembling the organism were confirmed by biochemical reactions (Willis, 1977; Jousimies-Somer et al., 2002).

\section{Toxin Testing by ELISA}

Detection of toxins $\mathrm{A}$ and $\mathrm{B}$ of $C$. difficile was performed using $C$. difficile Toxin $\mathrm{A}+\mathrm{B}$ 2nd Generation ELISA Kit according to the manufacturer's instructions. The results were read spectrophotometrically at $450 \mathrm{~nm}$ wavelength.

\section{Statistical Analysis}

Statistical presentation and analysis of data in the present study was conducted using the mean, standard deviation and Chi- square test by SPSS V.16. P value of $\square 0.05$ indicated statistical significance.

\section{Results and Discussion}

Stool samples of 60 non neonate infants and children cases received antibiotics and 30 control patients with no history of antibiotic intake were collected over the period of the study. Demographic, clinical and laboratory data of the studied group and their controls were summarized in table 1.

The specimens collected from the cases and cultured on CCFA were classified as positive and negative according to $C$. difficle isolation and compared in table 2 .

The percentage of $C$. difficile and their toxins among the studied cases with or without diarrhea were illustrated in table 3.

Antibiotic administration in the studied cases with positive and negative stool cultures was illustrated in table 4.

C. difficile is a gram positive anaerobic sporulating rods that causes a variety of clinical presentations ranging from asymptomatic carrier state, mild diarrhea to severe debilitated disease that may be fatal in some cases (Beaulieu et al., 2007; Vaishnavi, 2010).

Antibiotic is considered the well known risk factor for CDAD (Kaneria and Paul, 2012). C. difficile causes diarrhea through secretion of exotoxins (A, B) that are responsible for the pathogenicity and disease production (Voth and Ballard, 2005). 
The scope of the present study includes the isolation of $C$. difficile by culture, identification of $C$. difficile colonies by biochemical reactions, detection of toxins $\mathrm{A}$ and $\mathrm{B}$ by ELISA among pediatric patients with diarrhoea and thereby detecting the incidence of CDI in the studied group.

CDAD is still not well recognized in Egypt due to lack of clinical suspicion, cost of the toxin assay and difficulty in culturing the organism. Therefore we undertook a prospective study to determine the incidence of CDAD in our hospital.

Among 60 infants and children previously treated with antibiotics for 10 days or more, 26 cases $(43.3 \%)$ showed clinical diarrhea, 22 cases $(36.7 \%)$ had positive stool culture for $C$. difficile, and 16 cases (26.7\%) showed C. difficile toxins in stools by ELISA. Our results were somewhat higher than the study done by Justin et al. (2015) who reported that $(15.22 \%)$ of samples were culture positive for $C$. difficile and only (10.87\%) of isolates from cases with diarrhea were positive for $C$. difficile toxins $\mathrm{A}$ and $\mathrm{B}$ by EIA. The higher incidence of toxic isolates in our study may be due to the presence of four cases from total 16 with toxigenic $C$. difficile were on antibiotics but had no diarrhea.

None of the control infants and children had diarrhea and all of them were negative for $C$. difficile organism and toxin. The difference between case and control was significant, indicating significant relationship between antibiotic administrations and $C$. difficile diarrhea or colonization. (table1)

These results agreed with the study performed by Levy (2000) who reported that antibiotics lead to increased susceptibility to the acquisition of $C$. difficile. Similarly, McFarland (1998) reported that diarrhea is a common complication of antibiotics which occurs in between 5\% to $39 \%$ of patients. This effect is caused by disturbance of the normal balance of intestinal organisms.

On the other hand our results disagreed with Wistrom et al. (2001) who stated that antibiotic associated diarrhea can occur up to 2-3 weeks following cessation of antibiotic therapy rather than during the treatment. The same was reported by Niyogi et al. (1991) who stated that $C$. difficile cytotoxin has been reported in $7 \%$ of studied patients, in a hospital in Calcutta, who did not had prior antibiotics.

In this study toxin was detected in 12 out of 26 cases with diarrhea so the incidence of CDAD was $(46.2 \%)$. These findings were much higher than results obtained by Kaneria and Paul (2012) \& Turck et al. (2003) who reported that the incidence of CDAD in their hospital was $10 \%$ and $11 \%$ respectively. Turck et al. (2003) study included children in outpatient setting and this may be the cause of this big difference between their results and ours as CDAD is primarily acquired from the hospital environment, which leads to the higher incidence noted in hospitalized patients who are treated with antibiotics, compared with those in outpatient settings .

The results of the current study were somewhat higher than Gupta et al. (1985) who isolated $C$. difficile from $25.3 \%$ of hospitalized patients with diarrhea. Also, Vaishnavi et al. (1999) reported 30\% positivity for $C$. difficile toxin in hospitalized patients of all age groups receiving antibiotics for various diseases. Moreover, McFarland (2007) reported that C. difficile associated diarrhea was the etiology of $30 \%$ of all studied pediatric patients with diarrhea. 
Table.1 Demographic, Clinical and Laboratory Data of the Studied Cases and their Controls

\begin{tabular}{|c|c|c|c|c|c|c|}
\hline & \multicolumn{2}{|c|}{$\begin{array}{c}\text { Cases } \\
\text { (antibiotic intake) }\end{array}$} & \multicolumn{2}{|c|}{$\begin{array}{l}\text { Controls } \\
\text { (No antibiotic } \\
\text { intake) }\end{array}$} & \multirow[t]{2}{*}{$\mathrm{X}^{2}$ test } & \multirow[t]{2}{*}{ p-value } \\
\hline & No. & $\%$ & No. & $\%$ & & \\
\hline Total & 60 & $100 \%$ & 30 & $100 \%$ & & \\
\hline $\begin{array}{l}\text { Age (months) } \\
\text { mean } \pm \text { SD }\end{array}$ & \multicolumn{2}{|c|}{$49.6 \pm 31$} & \multicolumn{2}{|c|}{$25.6 \pm 21.4$} & 0.335 & 0.739 \\
\hline $\begin{array}{l}\text { Sex } \\
\text { Male } \\
\text { Female }\end{array}$ & $\begin{array}{l}30 \\
30\end{array}$ & $\begin{array}{l}50.0 \% \\
50.0 \%\end{array}$ & $\begin{array}{l}16 \\
14\end{array}$ & $\begin{array}{l}53.3 \% \\
46.7 \%\end{array}$ & 0.044 & 0.833 \\
\hline $\begin{array}{l}\text { Mode of delivery } \\
\text { NVD } \\
\text { C.S }\end{array}$ & $\begin{array}{l}40 \\
20 \\
\end{array}$ & $\begin{array}{l}66.7 \% \\
33.3 \% \\
\end{array}$ & $\begin{array}{l}16 \\
14 \\
\end{array}$ & $\begin{array}{l}53.3 \% \\
46.7 \% \\
\end{array}$ & 0.756 & 0.384 \\
\hline $\begin{array}{l}\text { Type of feeding } \\
\text { Breast feeding } \\
\text { Artificial feeding } \\
\text { Food } \\
\end{array}$ & $\begin{array}{l}24 \\
22 \\
14\end{array}$ & $\begin{array}{l}40.0 \% \\
36.7 \% \\
23.3 \%\end{array}$ & $\begin{array}{l}8 \\
6 \\
16 \\
\end{array}$ & $\begin{array}{l}26.7 \% \\
20.0 \% \\
53.3 \%\end{array}$ & 4.093 & 0.129 \\
\hline $\begin{array}{l}\text { Stool Consistency } \\
\text { Diarrhea } \\
\text { No diarrhea }\end{array}$ & $\begin{array}{l}26 \\
34\end{array}$ & $\begin{array}{l}43.3 \% \\
56.7 \%\end{array}$ & $\begin{array}{l}0 \\
30\end{array}$ & $\begin{array}{l}0.0 \% \\
100.0 \%\end{array}$ & 9.141 & $0.002 * *$ \\
\hline $\begin{array}{l}\text { Stool culture for } \quad \text { C. } \\
\text { difficile } \\
+ \text { ve } \\
-\mathrm{ve}\end{array}$ & $\begin{array}{l}22 \\
38 \\
\end{array}$ & $\begin{array}{l}36.7 \% \\
63.3 \%\end{array}$ & $\begin{array}{l}0 \\
30\end{array}$ & $\begin{array}{l}0.0 \% \\
100.0 \% \\
\end{array}$ & 7.279 & $0.007 * *$ \\
\hline $\begin{array}{l}\text { Toxin detected by ELISA } \\
+\mathrm{ve} \\
\text {-ve }\end{array}$ & $\begin{array}{l}16 \\
44 \\
\end{array}$ & $\begin{array}{l}26.7 \% \\
73.3 \%\end{array}$ & $\begin{array}{l}0 \\
30\end{array}$ & $\begin{array}{l}0.0 \% \\
100.0 \%\end{array}$ & 4.14 & $0.04 *$ \\
\hline
\end{tabular}

This table showed that there was no statistically significant difference between studied cases and their controls as regards, age, sex, mode of delivery and the type of feeding. But there was a statistically significant relation between diarrhea and antibiotic intake $(\mathrm{P}<0.05)$. Also $C$. difficile detection by stool culture and the presence of their toxins in stools was significantly higher in the studied cases than their controls $(\mathrm{P}<0.05)$ 
Table.2 Comparison between C. difficile Positive and Negative Cultures among the Studied Infants and Children Cases

\begin{tabular}{|c|c|c|c|c|c|c|}
\hline & \multicolumn{4}{|c|}{ Cases } & \multirow[t]{4}{*}{$\mathrm{X}^{2}$ test } & \multirow[t]{4}{*}{ p-value } \\
\hline & \multicolumn{4}{|c|}{ Stool culture for C. difficile } & & \\
\hline & \multicolumn{2}{|c|}{$+\mathrm{ve}$} & \multicolumn{2}{|c|}{$-\mathrm{ve}$} & & \\
\hline & No. & $\%$ & No. & $\%$ & & \\
\hline Total & 22 & $100 \%$ & 38 & $100 \%$ & & \\
\hline $\begin{array}{l}\text { Sex } \\
\text { Male } \\
\text { Female }\end{array}$ & $\begin{array}{l}10 \\
12 \\
\end{array}$ & $\begin{array}{l}45.5 \% \\
54.5 \% \\
\end{array}$ & $\begin{array}{l}20 \\
18 \\
\end{array}$ & $\begin{array}{l}52.6 \% \\
47.4 \% \\
\end{array}$ & 0.144 & 0.705 \\
\hline $\begin{array}{l}\text { Type of feeding } \\
\text { Breast feeding } \\
\text { Artificial feeding } \\
\text { Food }\end{array}$ & $\begin{array}{l}6 \\
8 \\
8\end{array}$ & $\begin{array}{l}27.3 \% \\
36.4 \% \\
36.4 \%\end{array}$ & $\begin{array}{l}18 \\
14 \\
6\end{array}$ & $\begin{array}{l}47.4 \% \\
36.8 \% \\
15.8 \% \\
\end{array}$ & 1.968 & 0.374 \\
\hline $\begin{array}{l}\text { Stool Consistency } \\
\text { Diarrhea } \\
\text { No diarrhea }\end{array}$ & $\begin{array}{l}18 \\
4 \\
\end{array}$ & $\begin{array}{l}81.8 \% \\
18.2 \% \\
\end{array}$ & $\begin{array}{l}8 \\
30 \\
\end{array}$ & $\begin{array}{l}21.1 \% \\
78.9 \% \\
\end{array}$ & 10.476 & $0.001 * *$ \\
\hline $\begin{array}{l}\text { Toxin detected by ELISA } \\
+ \text { ve } \\
\text {-ve }\end{array}$ & $\begin{array}{l}16 \\
6\end{array}$ & $\begin{array}{l}72.7 \% \\
27.3 \%\end{array}$ & $\begin{array}{l}0 \\
38\end{array}$ & $\begin{array}{l}0.0 \% \\
100.0 \%\end{array}$ & 15.77 & $\square \mathbf{0 . 0 0 1} * *$ \\
\hline $\begin{array}{l}\text { Duration of antibiotic } \\
\text { therapy before inclusion in } \\
\text { research (days) } \\
\text { mean } \pm \text { SD }\end{array}$ & 15.3 & & $14.9 \pm 6$ & & 0.158 & 0.270 \\
\hline
\end{tabular}

This table showed that there was no statistically significant difference between $C$. difficile positive and negative cases among studied infants and children as regards, sex, type of feeding, type of diarrhea, frequency of diarrhea, age and duration of antibiotic therapy.

While $C$. difficile detection by culture and their toxins by ELISA among cases with diarrhea was significantly high when compared to cases without diarrhea after antibiotic intake $(\mathrm{p}<0.05)$

Table.3 The Percentage of C. difficile and their Toxins among the Studied Cases with or without Diarrhea

\begin{tabular}{|c|c|c|c|c|c|c|c|}
\hline \multirow{2}{*}{$\begin{array}{l}\text { Culture on } \\
\text { CCFA }\end{array}$} & \multirow{2}{*}{$\begin{array}{l}\text { Toxin } \\
\text { detected } \\
\text { by } \\
\text { ELISA }\end{array}$} & \multicolumn{2}{|c|}{ Diarrhea } & \multirow{2}{*}{$\begin{array}{l}\text { Culture } \\
\text { on } \\
\text { CCFA }\end{array}$} & \multirow{2}{*}{$\begin{array}{l}\text { Toxin } \\
\text { detected } \\
\text { by } \\
\text { ELISA }\end{array}$} & \multicolumn{2}{|c|}{ No diarrhea } \\
\hline & & $\mathrm{No}=26$ & $\%$ & & & $\mathrm{No}=34$ & $\%$ \\
\hline \multirow[t]{2}{*}{ +ve (18) } & +ve & 12 & 66.6 & \multirow[t]{2}{*}{ +ve (4) } & +ve & 4 & 100.0 \\
\hline & -ve & 6 & 33.3 & & -ve & 0 & 0.0 \\
\hline \multirow{2}{*}{$\begin{array}{l}\text {-ve } \\
(8)\end{array}$} & +ve & 0 & 0.0 & \multirow[t]{2}{*}{-ve (30) } & $+\mathrm{ve}$ & 0 & 0.0 \\
\hline & -ve & 8 & 100.0 & & -ve & 30 & 100.0 \\
\hline
\end{tabular}

This table showed that $46.2 \%$ (12 out of 26) of patients with antibiotic associated diarrhea were infected by toxigenic $C$. difficile so the incidence of CDAD was (46.2 \%).. While 4 out of the 34 cases with no diarrhea were colonized with toxigenic $C$. difficle and were considered as asymptomatic carriers representing (11.8\%) 
Table.4 Antibiotic Administration in the Studied Cases with Positive and Negative Stool Cultures

\begin{tabular}{|c|c|c|c|c|c|c|}
\hline \multirow{3}{*}{ Antibiotics } & \multicolumn{4}{|c|}{ Stool culture } & \multirow{3}{*}{$\begin{array}{c}\mathbf{X}^{2} \\
\text { Mann- } \\
\text { Whitney }\end{array}$} & \multirow{3}{*}{ p-value } \\
\hline & \multicolumn{2}{|c|}{$\begin{array}{c}\text { C. difficile +ve } \\
\text { culture } \\
(\text { total 22) }\end{array}$} & \multicolumn{2}{|c|}{$\begin{array}{c}\text { C. difficile -ve } \\
\text { culture } \\
\text { (total 38) }\end{array}$} & & \\
\hline & No. & $\%$ & No. & $\%$ & & \\
\hline Penicillins & 22 & $100 \%$ & 34 & $89.47 \%$ & 1.24 & 0.27 \\
\hline Aminoglycosides & 10 & $45.45 \%$ & 16 & $53.33 \%$ & 0.03 & 0.86 \\
\hline Cephalosporins & 20 & $90.9 \%$ & 30 & $78.94 \%$ & 0.72 & 0.40 \\
\hline Carbapenems & 4 & $18.18 \%$ & 8 & $21.05 \%$ & 0.04 & 0.85 \\
\hline Clindamycin & 2 & $09.09 \%$ & 4 & $10.52 \%$ & 0.02 & 0.90 \\
\hline Quinolones & 4 & $18.18 \%$ & 8 & $21.05 \%$ & 0.04 & 0.85 \\
\hline
\end{tabular}

This table showed that penicillins, cephalosporins and aminoglycosides were the most commonly used antibiotics associated with CDI. Moreover, there was no statistically significant difference between studied cases with $C$. difficile positive and negative cultures and one type of antibiotics used

On the other hand results obtained by Wistrom et al. (2001), showed that $C$. difficile contributed to more than $55.4 \%$ of diarrheal inpatients from five Swedish hospitals with great variance among the hospitals themselves obtained as high as $62.5 \%$ of tested patients in one of the studied centers. These results are slightly higher than ours because the study was done on adult patients.

Our study also showed that 4 out of the 34 cases with no diarrhea were colonized with toxigenic $C$. difficle and were considered as asymptomatic carriers whose toxin levels were low and not sufficient to produce symptoms and representing (11.8\%) (table 4).

This result was higher than results of Kaneria and Paul (2012) who reported that the toxigenic $C$. difficile asymptomatic carriage rate was $6 \%$. This difference may be due to environmental considerations and different population factors.

The current study showed that there was no statistically significant difference between studied cases with $C$. difficile positive and negative cultures and one type of antibiotics used.

These results agreed with McFarland (1998), who stated that the occurrence of antibiotic associated diarrhea varies greatly and is influenced by a number of factors other than the type of antibiotic used, including nosocomial outbreaks, patterns of antimicrobial use, individual susceptibility and the length of hospitalization (the infection rates for $C$. difficile are reported to be around $10 \%$ after 2 weeks of hospitalization but may reach $50 \%$ after 4 or more weeks).

As regard to antibiotics used in the cases of study, we found that penicillin was used in all cases with positive $C$. difficile infection followed by cephalosporins (90.9\%) and aminoglycosies $(45.45 \%)$ although it was not statistically significant when compared with culture negative cases. Our observations were in accordance with the results of van der Kooi et al. (2008); King and Lager (2011); Kaneria and Paul (2012) who observed that previous treatment with cephalosporins is associated with high incidence of CDAD 
Other study done by Takahashi et al. (2014) reported that the use of all types of intravenous antibiotics was significantly more prevalent in the CDI group than the control group. No significant differences were identified between the two groups with respect to oral antibiotic use. While our study showed no statistically significant differences between the two groups in all types of antibiotics used whether oral or intravenous.

In conclusion, Antibiotic therapy is the main risk factor of CDI in infants and children. The incidence of CDAD in the studied cases of infants and children admitted to our hospital $46.2 \%$ of the 26 patients with AAD. This high incidence may be attributed to injudicious use of broad spectrum antibiotics, defects in infection control measures that help in minimizing the nosocomial transmission of $C$. difficile among hospitalized patients. The asymptomatic carriage rate was $11.8 \%$. All the cases had mild to moderate diarrhea. None of our studied cases had complications or mortality.

\section{Acknowledgment}

The authors thank the staff members of Pediatrics and Microbiology departments, Tanta Faculty of Medicine for their valuable cooperation and support during the study. The authors also thank the participants themselves and their families.

\section{References}

Beaulieu, M., Williamson, D., Pichette, G., Lachaine, J. 2007. Risk of Clostridium difficile-associated disease among patients receiving proton-pump inhibitors in a Quebec medical intensive care unit. Infect. Control Hosp. Epidemiol., 28:1305-1307.
Center for Disease Control and Prevention, 2013. Antibiotic resistance threats in the United States. Available: 'http://Www.cdc.gov/drugresistance/thre at-report-2013/pdf/ar-threats-2013508.pdf. Áccessed 2015 Nov 8.

Cerquetti, M., Luzzi, I., Caprioli, A., Sebastianelli, A., Mastrantonio, P. 1995. Role of Clostridium difficile in childhood diarrhea. Pediatr. Infect. Dis. J., 14(7): 598-603.

Ferri, F.F. 2010. Pseudomembranous colitis. In: Ferri FF (Ed.). Ferri's Clinical Advisor. $4^{\text {th }}$ ed. Philadelphia (PA), Mosby Elsevier, pp. 323-328.

Gupta, U., Yadav, R.N. 1985. Clostridium difficile in hospital patients. Indian $\mathbf{J}$. Med. Res., 82: 398-401.

Hall, I.C., O'Toole, E. 1935. Intestinal flora in new-born infants: with a description of a new pathogenic anaerobe, Bacillus difficilis. Am. J. Dis. Child, 49:390402.

Hung, Y.P., Lee, J.C., Lin, H.J., Liu, H.C., Wu, Y.H., Tsai, P.J., Ko, W.C. 2015. Clinical impact of Clostridium difficile colonization. J. Microbiol. Immunol. Infect., 48, 241-248.

Hurley, B.W., Nguyen, C.C. 2002. The spectrum of pseudomembranous enterocolitis and antibiotic-associated diarrhea. Arch. Intern. Med.,162: 2177-84.

Jousimies-Somer, H.R., Summanen, P., Citron, D.M., Baron, E.J., Wexler, H.M., Finegold, S.M., Wadsworth, K.T.L. 2002. Anaerobic Bacteriology Manual. $6^{\text {th }}$ ed. Belmont: Star Publishing Company.

Justin, S., Antony, B., Shenoy, K.V., Boloor, R. 2015. Prevalence of Clostridium Difficile Among Paediatric Patients in a Tertiary Care Hospital, Coastal Karnataka, South India. Journal of Clinical and Diagnostic Research, 9 (2): DC04-DC07. 
Kaneria, M.V., Paul, S. 2012. Incidence of Clostridium difficile associated diarrhoea in a tertiary care hospital. J. Assoc. Physicians India., 60:26-8.

Kim, J., Shaklee, J.F., Smathers, S., Prasad, P., Asti, L., Zoltanski, J., Dul, M., Nerandzic, M., Coffin, S.E., Toltzis, P., Zaoutis, T. 2012. Risk factors and outcomes associated with severe Clostridium difficile infection in children. Pediatr. Infect. Dis. J., 31:134-138.

King, R.N., Lager, S.L. 2011. Incidence of Clostridium difficile infections in patients receiving antimicrobial and acid-suppression therapy. Pharmacotherapy, 31:642-648.

Knecht, H., Neulinger, S.C., Heinsen, F.A., Knecht, C., Schilhabel, A., Schmitz, R.A., Zimmermann, A., Santos, V.M., Ferrer, M., Rosenstiel, P.C., Schreiber, S., Friedrichs, A.K., Ott, S.J. 2014. Effects of b-Lactam Antibiotics and Fluoroquinolones on Human Gut Microbiota in Relation to Clostridium difficile Associated Diarrhea. PLoS ONE 9(2): e89417.

Kyne, L., Hamel, M.B., Polavaram, R., Kelly, C.P. 2002. Health care costs and mortality associated with nosocomial diarrhea due to Clostridium difficile. Clin. Infect. Dis., 34: 346-53.

Larson, H.E., Price, A.B., Honour, P., Borriello, S.P. 1978. Clostridium difficile and the aetiology of pseudomembranous colitis. Lancet, 1:1063-1066.

Levy, J. 2000. The effects of antibiotic use on gastrointestinal function. Am Gastroenterol., 95, S8-S10.

McFarland LV,(1998): Epidemiology, risk factors and treatments for antibioticassociated diarrhea. Dig. Dis.,16:292307.

McFarland, L.V. 2007. Diarrhoea associated with antibiotic use. British Medical
Journal, 335: 54-55.

Niyogi, S.K., Dutta, P., Dutta, D., Mitra, U., Sikdar, S. 1991. Clostridium difficile and its cytotoxin in hospitalized children with acute diarrhea. Indian Pediatr., 28(10): 1129-32.

Pokorn, M., Radsel, A., Cizman, M., Jereb, M., Karner, P., Kalan, G. Grosek, S., Andlovic, A., Rupnik, M. 2008. Severe Clostridium difficile-associated disease in children. Pediatr. Infect. Dis. J., 27:944-946.

Sharland, M.C., Cant, A., Shingadia, D. 2011. Clostridium difficile infection. In: Manual of childhood infections: the blue book. Oxford, pp. 487-495.

Takahashi, M., Mori, N., Bito, S. 2014. Multi- institution case- control and cohort study of risk factors for the development and mortality of Clostridium difficile infections in Japan. BMJ Open., 4 (9): e005665.

Turck, D., Bernet, J.P., Marx, J., Kempf, H. ,Giard, P., Walbaum, O., Lacombe, A., Rembert, F., Toursei, F., Bernasconi, P. 2003. Incidence and risk factors of oral antibiotic associated diarrhea in an outpatient pediatric population. Journal of Pediatric gastroenterology And Nutrition, 37: 22-26

Vaishnavi, C., Kochhar, R., Bhasin, D.K., Thapa, B.R., Singh, K. 1999. Detection of Clostridium difficile toxin by an indigenously developed latex agglutination assay. Trop. Gastroenterol., 20:33-5.

Vaishnavi, C. 2010. Clinical spectrum \& pathogenesis of Clostridium difficile associated diseases. Indian J. Med. Res., 131:487-99.

van der Kooi TI, Koningstein M, Lindemans A, Notermans DW, Kuijper E, van den Berg R. 2008. Antibiotic use and other risk factors at hospital level for outbreaks with Clostridium difficile PCR ribotype 027. J. Med. Microbiol., 
57:709-716.

Voth, D.E., Ballard, J.D. 2005. Clostridium difficile toxins: mechanism of action and role in disease. Clin. Microbiol. Rev., 18:247-263.

Wilcox, M.H. 2003. Gastrointestinal disorders and the critically ill. Clostridium difficile infection and pseudomembranous colitis. Best Pract. Res. Clin. Gastroenterol., 17: 475-93.

Willis, A.T. 1977. Anaerobic Bacteriology: Clinical and Laboratory Practice. 3rd ed. London: Butterworth and Co (Publishers) Ltd.

Wistrom, J., Norrby, S.R., Myhre, E., Ericsson, S., Granstorm, G.,
Lagergrenr, L., Englund, G., Nord, C.E., Svenungsson, B. 2001. Frequency of antibiotic-associated diarrhoea in 2462 antibiotic- treated hospitalized patients: A prospective study. Antimicrob. Chemother., 47:43-50.

Zilberberg, M.D., Shorr, A.F., Kollef, M.H. 2008a. Increase in adult Clostridium difficile-related hospitalizations and case-fatality rate, United States, 2000 2005. Emerg. Infect. Dis., 14:929-931. Zilberberg, M.D., Shorr, A.F., Kollef, M.H. 2008 . Increase in Clostridium difficilerelated hospitalizations among infants in the United States, 2000-2005. Pediatr. Infect. Dis. J., 27:1111-1113.

\section{How to cite this article:}

Marwa Ahmed Ali Abd El-Wahab, Ahmed Mohamed Naeem, Abd EL- Rahman Mohamed EL-Mashad and Nehad Refhat Mostafa Sallam. 2016. Antibiotic Associated Diarrhea and Incidence of Clostridium difficile Infection and Colonization in Infants and Children in Tanta University Hospital, Egypt. Int.J.Curr.Microbiol.App.Sci. 5(1): 576-585 http://dx.doi.org/10.20546/ijcmas.2016.501.059 